\title{
Human Geography
}

\section{Author(s): H. J. Fleure}

Source: The Geographical Journal, Vol. 34, No. 6 (Dec., 1909), pp. 659-663

Published by: geographicalj

Stable URL: http://www.jstor.org/stable/1777952

Accessed: 28-06-2016 00:16 UTC

\section{Your use of the JSTOR archive indicates your acceptance of the Terms \& Conditions of Use, available at}

http://about.jstor.org/terms

JSTOR is a not-for-profit service that helps scholars, researchers, and students discover, use, and build upon a wide range of content in a trusted digital archive. We use information technology and tools to increase productivity and facilitate new forms of scholarship. For more information about JSTOR, please contact support@jstor.org.

The Royal Geographical Society (with the Institute of British Geographers), Wiley are collaborating with JSTOR to digitize, preserve and extend access to The Geographical Journal 
'The value of 'Die Alpen in Eiszeitalter' to geographers is twofold, as above stated. It describes many examples of many kinds of land forms in view of their origin; and it correlates these forms so that they all take systematic and orderly position in the valley systems of a glaciated mountain range. An explorer who now masters the details of a glaciated valley system, as he might a score or more years ago have mastered the details of a normal valley system, will find himself thereby vastly better equipped for intelligent and effective observation, than if he sets out on his journey with only an empirical knowledge of land forms. A reader who is familiar with the systematic distribution of parts in both normal and glacial valley systems, is far better prepared to appreciate the descriptions of well-equipped explorers than if he regarded all the items of land forms separately. But there is still further progress to be made. The details of a normal valley system vary, not only with their place in the system, but also with the stage of development that the system has reached: for this reason, it is helpful to use such terms as young, mature, and old in the genetic descriptions of normal valley systems. Likewise the features of a glaciated valley system must vary with its stage of development. Although we are as yet not well informed as to the changes in glacial valley systems as they pass through youth and maturity to old age, it cannot be for a moment doubted that they do suffer a sequence of changes as time passes; and it is now the evident duty of the glacialist, be he geographer or geologist, to determine what this sequence is, and to propose terms, such as young, mature, and old, by which its stages may be briefly and suggestively designated. Still further, just as normal cycles of erosion, one following another, produce a compound topography, and just as the character of the compound will depend on the stages reached in the several cycles, so normal and glacial cycles of erosion may be combined to produce a compound result, and the character of the result will depend on the stages reached in the several cycles. The Alps show us a compound of, for the most part, normally subdued (or late mature) mountains, several times severely glaciated, and now suffering normal erosion again; but we may conceive many other combinations. The Rocky mountains of Colorado were moderately glaciated after having been normally subdued. Norway has been intensely glaciated after the immature dissection of its uplifted highland. The heavy glaciation of the Laurentian uplands acted on an immaturely dissected peneplain. With the accumulation of such examples many idealized concepts must be elaborated, just as Penck and Brïckner elaborated the concept of the terminal Alpine drift deposits; and these idealized concepts must include all sorts of compounds of all kinds of mountains and all degrees of glaciation. The thoroughly prepared specialist in the exploration of land forms must, in the near future, be as well acquainted with the many combinations and permutations of these and other factors as the practised sportsman is with the ways of his wild game. All future studies of glaciated mountains will find their indispensable foundation in 'Die Alpen im Eiszeitalter.'

\section{HUMAN GEOGRAPHY.*}

M. Rechus (who died before the complete publication of his last work) says that Man is Nature becoming conscious of herself, and from this standpoint he attempts a broad survey of the circumstances which Nature provided for early man, and

* 'L'homme et La Terre.' Elisée Réclus. 6 vols. Paris : Librairie Universelle. 1905-08. 
of the work of mankind in adapting itself to those circumstances, and also in altering them here and there by adding new factors which have influenced succeeding generations. In studying present-day human facts, it is obviously necessary to see into not only the underlying physical non-human facts, but also the facts of the past. Esquimault was chosen, for reasons of a physical nature, as a harbour for the navy, but a speedy change of policy brought about the decay of this township without a past. Bristol, on the other hand, while owing its original importance and its site to reasons of physical geography, maintains its greatness in spite of many vicissitudes of trade; the accumulated momentum sprung from a long business tradition has tided the city over serious crises between the decay of one business and the evolution of another. One can, indeed, never assert what facts may and what facts may not be of geographical import, and M. Reclus boldly assumes that nothing human is foreign to his scheme. This makes the work in a sense a sketch of human evolution as well as a geographical study of the ways and works of the race. The net is large, and the meshes occasionally very fine, but it is obvious that no author can make himself a specialist in all departments of human knowledge, and the result is that M. Reclus's statements are frequently open to detailed criticism by the possessors of special scholarship. The work is, none the less, valuable and interesting, for there is much to be gained from a broad survey, which often suggests correlations and interweaving of influences the specialist might otherwise disregard.

M. Reclus's writing illustrates in most interesting fashion one of the greatest difficulties of work on human evolution, the tendency to sink back from the high and difficult line of scientific observation and inference, aided by the use of the imagination so valuable for work on mankind, and to indulge in criticisms and discussions, of which the primary interest is the light they shed on their author's own personality. We often find the author digressing for several pages on topics which are hardly germane to a geographical study, in order to set forth his individual views even on such controverted questions as those of religion. In this connection it may be said that this book is written from the standpoint involved in the national motto, "Liberté, Égalité, Fraternité," and that it is strongly anti-clerical. The book is therefore essentially a book to be studied very critically, but, remembering this, it is still possible to read its easily flowing sentences with pleasure, and to derive mental profit from its many-sided contact with human affairs.

The book seeks to relate human facts to the underlying physical circumstances at every point, and thence shows very clearly how much more dominant and exclusive was the influence of those immediate circumstances in early days than in more civilized epochs, when, nevertheless, the effects of that dependence on circumstance steal subtly through the strongest artificialities of social convention. The Eskimo hunters must be able to resist the pangs of hunger often for long periods, and this is reflected in their training of the young and in their physical and general characteristics. Many African tribesmen of the tropical plains must, on the other hand, be always on the alert and always fleet of foot, and in connection with this we find them frugal in their meals, of spare strong figure, and with senses keener than the average.

As a Western, M. Reclus naturally takes for the main thread of his narrative the influences operating upon Western civilization, and considers other peoples more especially in their relation to ourselves. This explains an emphasis on such subjects as the Jews and their religious ideas, an emphasis which at times leads the author far away from the business in hand-that of tracing the mutual influences of the Earth and man. 
The introductory survey deals with prehistoric man as known from the remains which have been found, and discusses in a general way his circumstances during the glacial period in Europe, in each case without raising any specifically new points. From this basis the author builds up an interesting account of the various types of incipient societies as they were probably influenced by their surroundings,- - by heat and cold, by drought and damp, by mountains, steppes, forests, rivers, marshes, lakes, islands, and the sea. In this connection the important point is made, that it is unwise to imagine a regular succession of sociological types, e.g. from gatherers to hunters, thence to pastoralists, and so on to agriculturalists, and ultimately industrialists. In different circumstances the different activities may appear in very different orders; thus the proximity of a navigable river may lead to the growth of commerce at a very early stage if the difficulty of navigation is surmounted, even ever so crudely. Life in mountain valleys is influenced by deficiency of light, by the streaming dampness of the hillsides, by the difficulties of winter travel, and, still more, of winter labour. The men of such valleys, therefore, descend to the plains to seek work for the winter, and in this way develop the habit of periodical, and ultimately of permanent, emigration which is such a characteristic of the Swiss, the Scotch, and the Welsh peoples. The unequalled difficulties of virgin forests as a home for man are well set forth; the damp semi-darkness and the trackless tangle of undergrowth tend to bring about a supreme isolation and to make the pigmies perhaps the most backward of all human types. Stress is laid on the importance of rivers as channels of intercourse and of unification in many cases, though not in all, for a river may be bounded by marshes which prevent access to its navigable course, or it may flow too strongly to permit navigation. A river can therefore, according to circumstances, become a means of intercourse or the reverse, and cases of both kinds can easily be adduced. There remains the further fact that rivers are found to be convenient boundaries of political states in later times, but political states are only occasionally natural entities.

There is an interesting chapter on the relations of early man and animals, and in it the author lays stress on the likelihood of wild animals acquiring the habit of prowling about the refuse heaps and surroundings of a savage encampment. Once this habit developed, the animals would lose some of their wildness and might come regularly in search of focd, thus giving up their shyness towards savage man. Whatever else is doubtful, it is at least reasonably certain that some indefinable and now lost quality made it possible for early man and animals to associate together, and the half-wild visitors to the camp could become pets and ultimately in the full sense domestic animals, the extension of the activity of the mammary glands in the cow being a further triumph in this direction. Reclus claims that the domestication of animals is a far easier step than the utilization and growing of plants, and he gives an interesting case of a monkey which, on its own initiative, did the work of a sheep-dog in Africa. It drove the flocks in, and even mounted them and bunted the parasites in their wool.

Another introductory section deals with the personal organization of society, and thereby touches the thorny controversy of the growth of types of marriage and of the matriarchal and patriarchal arrangements of social affairs. The infuence of geographical and other circumstances on the development of these systems is reviewed; the status of women is higher in a sense among tribes which live by gathering and tilling, work in which women may take a large share, than among other tribes living on flocks and herds necessarily cared for and especially defended by the men. Among fisher-folk also the women may gain great social importance, remaining as heads of the household while the men are often only occasional visitors. The Matriarchate and the Patriarchate are thus rival types of social order which, as 
Réclus insists, are rarely worked out exclusively ; in any one case we shall usually find a mixture of both, and the balance of preponderance of one or other may change from time to time with alterations in the conditions of life. It will be understood that along with marriage and social order comes the question of religion and ceremonial, a subject which is evidently of special interest to the author. His position is that of an anthropological geographer endeavouring to show that all religious beliefs and ceremonies are a natural product, are evolutions from the farthest ages of the past. It is unfortunate that beneath this legitimate argument, there runs an undercurrent of bitterness against current creed and dogma, which is not justifiable in a primarily geographical treatise, and which leads the author into some superfluous and unconvincing digressions.

The periennial question of "East" and "West" naturally comes up for treatment at the commencement of the survey of our civilization, and the reader is wisely warned against such common fallacies as that of an inevitable westward trend in civilization. The natural barriers to intercourse are made responsible, along with the slight development of practical mechanical genius, for the isolation of the various types of civilization in the countries of the East, and special attention is drawn to the great band of inhospitable lands separating these civilizations from those of the Mediterranean and the West. European culture has developed later, and has been influenced again and again by the East, for isolation has not been by any means complete, and the continual mixture of types and social arrangements in Europe laas kept the Western civilization in relative instability open to new ideas and progress. The modern vast improvements in mechanical skill and the consequent diminution of barriers, finally, are made to point towards internationalism and the growth of world culture. The author is filled with an ideal of society based upon free criticism and exchange, a society in which national boundaries and prejudices, social inequalities, non-rational dogmas, and other fossils of human evolution shall not have part or lot.

The systematic survey of civilization begins as early as documentary evidence permits, as it is made to start from what may be called the Near East-Iran, Mesopotamia, Egypt, and the countries between. The Pamirs, it is true, are the centre of the great continental arch, but their physical conditions have repelled mankind, and Iran has become the land whence influences radiated to both east and west; it was their place of meeting, and legend has much to say of the age-long conflicts between Iran and Turan.

In treating each region, the approved geographical method is followed of discussing the physical conditions, and especially the relief of the land, from which arguments are drawn as to lines and means of communications, and as to the conditions of social development. Much attention is paid to the human aspect of buildings and other objects of artistic effort, with special reference to the growth of religions. At the outset, the oft-repeated but still very necessary warning is given against generalizing about blood-relationship from the facts of language. The author practically discards the slowly dying Aryan or Indo-Germanic myth.

Phœnicia rightly comes in for special treatment as the meeting-place of three continents, the entrepot for the trade of the ancient world, whence the products of the Far East, "spices and balm and myrrh," and also gold and precious gems and ivorywork, valuable materials of sufficiently small bulk to be carried by camels, were brought to the shores of the Great sea and thence distributed to Crete, and Greece, and Egypt, and the barbaric West. Interesting analogies are drawn between Phœnicia and nineteenth-century England, free-trading merchant nations, each, temporarily at any rate, necessary to the general civilization, and each possessing a scattered empire largely based upon trading outposts. The author's controversial 
interests lead him to treat Palestine more especially from the point of sciology and theology, and his detailed account borrows much from the results of modern biblical criticism.

It would serve no useful purpose to attempt to follow, within the limits of a short article, the progress of M. Reclus's survey, as he deals successively with the Roman Empire, the Barbarians, mediæval Europe, and the rise of the modern state. In each case the author's aim is to compile an interesting account of the civilization, monuments, and activities of the peoples successively discussed, and one only regrets that his strong personal likes and dislikes sometimes lead him into controversial accounts of political and psychological matters somewhat removed from the main thesis of the relation of man to the Earth. The survey ultimately wends its way around the whole inhabited Earth, and the section on contemporary history gives a broad statement of an educated Frenchman's standpoint in discussing modern international questions.

A rather acid discussion of Britain, especially in its rôle as a world power, is of sufficient interest to us to need special mention. M. Reclus seems to see in the well-known British love of continuity of tradition merely a blind conservatism which acts as a drag on the nation. For him the connection between the motherBritain and the Britains over-seas is a slender one likely to break, and South Africa is treated as a thorn in the side of the empire without a thought of the great scheme of the United States of South Africa which was so soon to be realized. Statistics are given to show the waning of England's industrial primacy, and for the author that was evidently the main feature of British greatness. The administrative work of the imperial civil service is sadly undervalued, while undue attention is paid to the extreme exuberance of British patriotism which has occasionally spread from a few enthusiasts to the mass of the people and infected them usually for a very short time. The British in India come in for special criticism, though the author admires their governmental sagacity, and takes comfort in the belief that British rule is bringing into existence a feeling of "India for the Hindoos." In several sections the author draws attention to the probable immense future importance of the East Indies, where a chain of islands is allowed to belong to Holland for the present but may change hands at any time, and through which opens the great sea-way into the Pacific, the ocean of the future. The concluding chapters contain a survey of modern social systems from the author's standpoint, and continue his criticisms of things British! He gives a caricature of the British Empire, a tall gaunt tourist in a Norfolk suit stalking "over the bodies of unfortunate subject peoples, with ironclads emerging from a cloud of black smoke in the background. Other illustrations are a procession of unemployed in London, and a nail-maker, with explanatory details from a report on sweated industries. M. Reclus is almost as critical of most other nations, and evidently distrusts a plutocracy even more than the older types of aristocracy, but, as befits an idealistanarchist, he concludes in an optimistic tone and looks forward to a successful war against poverty and ignorance, leading on to the realization of an International society of workers based upon "Liberté, Egalité, Fraternité."

\section{H. J. FreURe.}

